\title{
RECOVERY FROM THE COVID-19 RECESSION: UNEVEN EFFECTS AMONG YOUNG WORKERS?
}

\author{
Pinka Chatterji \\ Yue Li \\ Working Paper 29307 \\ http://www.nber.org/papers/w29307 \\ NATIONAL BUREAU OF ECONOMIC RESEARCH \\ 1050 Massachusetts Avenue \\ Cambridge, MA 02138 \\ September 2021, Revised December 2022
}

Yue Li has received grants from the NSF and SSA via the NBER for some other projects. The views expressed herein are those of the authors and do not necessarily reflect the views of the National Bureau of Economic Research.

NBER working papers are circulated for discussion and comment purposes. They have not been peer-reviewed or been subject to the review by the NBER Board of Directors that accompanies official NBER publications.

(C) 2021 by Pinka Chatterji and Yue Li. All rights reserved. Short sections of text, not to exceed two paragraphs, may be quoted without explicit permission provided that full credit, including () notice, is given to the source. 
Recovery from the COVID-19 Recession: Uneven Effects among Young Workers?

Pinka Chatterji and Yue Li

NBER Working Paper No. 29307

September 2021, Revised December 2022

JEL No. I0,J0

\begin{abstract}
$\underline{\text { ABSTRACT }}$
In this paper, we examine the labor market recovery from the COVID-19 recession and test for effects of termination of pandemic unemployment insurance programs among 15-24-year-olds. We use data from the January 2016-October 2022 Current Population Survey. Using regressionbased methods, we show that while 15-19-year-olds experienced a brisk, full recovery in labor market outcomes from the COVID-19 recession, the recovery was sluggish and incomplete among 20-24-year-olds, with some work outcomes lagging below pre-pandemic norms well into 2022. Termination of pandemic UI programs led to increased work hours and full-time employment among 20-24-year-olds but did not have these effects among 15-19-year-olds.
\end{abstract}

\author{
Pinka Chatterji \\ State University of New York at Albany \\ Economics Department \\ 1400 Washington Avenue \\ Albany, NY 12222 \\ and NBER \\ pchatterji@albany.edu \\ Yue Li \\ Department of Economics \\ SUNY Albany \\ 1400 Washington Avenue \\ Albany, NY 12222 \\ USA \\ yli49@albany.edu
}




\section{Introduction}

Economic downturns tend to harm young people’s labor market outcomes

disproportionately. Young workers have limited job tenure, education, and experience, and they tend to work in industries and occupations that are vulnerable to the business cycle (Hoynes et al., 2012). Research suggests that higher unemployment rates are associated with lower hiring rates, but only for the least experienced workers (Forsythe, 2022). Moreover, there is evidence of “scarring effects,” or lasting negative impacts of current economic downturns on young workers’ future labor market outcomes (Glatt \& Wunnava, 2018). Jobs obtained during recessions tend to be lower-paying and of lower quality compared to those found during expansions, and these effects have been found to be particularly damaging for the least experienced workers (Oreopoulos et al., 2012).

The COVID-19 downturn brought additional challenges for young workers compared to those of a typical recession, mainly because young workers are disproportionately represented in industries that were severely affected by the pandemic, such as leisure and hospitality, and wholesale and retail trade (Alon et al., 2020; Baker et al., 2020; Falk et al., 2021; Aaronson \& Alba, 2020; Kochhar \& Barroso, 2020). As expected, the initial labor market impact of the pandemic was largest for young workers (as well as for other disadvantaged groups), although in some cases, the hardest-hit groups also recovered the fastest (Lee et al. 2021). Prior studies have examined the effects of the pandemic on particular demographic groups (examples include Lee et al., 2021; CBPP, 2022; Goda et al. 2021; Borjas \& Cassidy, 2020; Alon et al., 2021), but these studies have not focused on labor market recovery among young workers.

In this paper, we examine the labor market recovery from the COVID-19 recession of two groups of young workers - teenagers (15-19-year-olds) and young adults (20-24-year-olds) 
- and we test for effects of termination of pandemic unemployment insurance (UI) programs in these two age groups. Exploring potential heterogeneity within young workers (teenagers vs. young adults) is important because: (1) teenagers have weaker labor force attachment than young adults and thus are less likely than young adults to be eligible for unemployment insurance (UI); and (2) effects of work on human capital accumulation may be quite different for teenaged workers, who are typically enrolled in school, vs. for young adult workers, many of whom have completed their educations and are building full-time work experience.

We use data from the January 2016-October 2022 Current Population Survey (CPS) (Flood et al., 2022). Using regression-based methods, we show that while 15-19-year-olds experienced a brisk, full recovery in labor market outcomes from the COVID-19 recession, the recovery was sluggish and incomplete among 20-24-year-olds, with some work outcomes lagging below pre-pandemic norms well into 2022. Termination of pandemic UI programs led to increased work hours and full-time employment among 20-24-year-olds but did not have these effects among 15-19-year-olds.

\section{Background}

The COVID-19 recession was the deepest and also the shortest recession in recent history (CBPP, 2022). This recession was fueled by both demand-side and supply-side shocks caused, to a large extent, by the need to stop the spread of disease by shutting down the economy (Gopinath, 2020; Handwerker et al., 2020). In response to the pandemic, the US Congress passed the $\$ 2$ trillion Coronavirus Aid, Relief, and Economic Security (CARES) Act on March 27, 2020. The new law created Pandemic Unemployment Assistance (PUA) which granted UI eligibility to some groups of workers who previously had been ineligible (e.g. self-employed workers, freelancers). This was particularly important for young workers. In addition, the 
CARES Act provided Federal Pandemic Unemployment Compensation (FPUC), a weekly additional payment of $\$ 600$ per week to calculated state UI benefits between April 5, 2020, and July 26, 2020; and provided Pandemic Emergency Unemployment Compensation (PEUC), an additional 13 weeks of UI once state UI benefits (which typically last 26 weeks) had expired, available until December 31, 2020 (NYS DOL 2021; Mishory \& Settner, 2020).

The $\$ 600$ additional UI benefits were extended to September 6, 2021, at a reduced amount of \$300 under the Lost Wage Assistance program, the Coronavirus Response and Relief Supplemental Appropriations Act of 2021, and the American Rescue Plan Act of 2021 (BEA, 2021). Twenty-six states, however, chose to end their participation in either or both FPUC and PUA before September 2021. Eighteen of these twenty-six states ended both FPUC and PUA in June 2021, while twenty-four states and DC continued both programs until the programs expired in September 2021 (Holzer et al. 2021). The rationale for these early terminations of pandemic UI was that that generous benefits possibly were dampening workers' efforts to find jobs and return to work (Holzer et al., 2021). Empirical research using a variety of data sets and study designs indicates that generous UI benefits during the pandemic had limited or no effects on employment (Altonji et al., 2020; Bartik et al., 2020; Finamor \& Scott, 2021; Petrosky-Nadeau \& Valletta, 2021; Ganong et al., 2021a-b). ${ }^{1}$ Researchers have started to estimate the effect of some states' early termination of pandemic FPUC and PUA in June and July 2021 on employment, and this work shows mixed effects (Holzer et al., 2021; Dube, 2021; Coombs et al. 2021).

All young workers have relatively low levels of job tenure, skills, and experience, but the 15-19 vs. 20-24 age groups differ in two respects that are relevant to the time-period following

\footnotetext{
${ }^{1}$ Marinescu et al. (2021) find that FPUC was associated with a 3.6 percent decrease in job applications and hence increased labor market tightness, which was depressed under the FPUC period.
} 
the COVID-19 recession. First, workers aged 15-19 face higher costs of working than those aged 20-24 since the vast majority of teenagers are enrolled in school; thus, a lower share of this age group is employed (as we discuss below). Second, relative to young adults, teenagers are less likely to be eligible for unemployment insurance (UI) because of failing to meet state regulations such as having sufficient work history (Mishory \& Stetter, 2020). For these reasons, we hypothesize that there was heterogeneity among young workers in labor market recovery from the COVID-19 recession.

This heterogeneity within young workers is important to study from a policy perspective. From a short-term policy perspective, firms' hiring of less-experienced teen workers during the pandemic may have benefitted both teenage workers as well as young adult workers who reduced work hours and received enhanced UI. The long-term policy implications, however, are unclear since young adult workers' later labor market outcomes may be harmed by these early disruptions in work (Glatt \& Wunnava, 2018; Santacrose, 2013). Moreover, the long-term effect on the younger group of teenaged workers is ambiguous, since working during the school year could negatively impact academic performance and time spent studying (Tyler, 2003; Rothstein, 2007; Kalenkoski \& Pabilonia, 2012) while working during summer months may improve academic performance (Leos-Urbel, 2014).

\section{Data and Methods}

The analysis sample includes childless respondents aged 15-24 who do not have college degrees; do not reside in group quarters; and are US citizens who were in a CPS household for at least one month between January 2016 and October 2022. Initially, using this sample, we estimate Equation 1 to map out the month-by-month effects of the pandemic on work outcomes for each age group (15-19, 20-24) during the pandemic: 


$$
y_{\text {iast }}=\sum_{\tau=-13}^{-1} \delta^{\tau} D_{i t}^{\tau}+\sum_{\tau=1}^{32} \delta^{\tau} D_{i t}^{\tau}+\eta t_{t}+\gamma_{a t}+\gamma_{s}+X_{\text {iast }} \theta+\epsilon_{\text {iast }}
$$

In Equation 1, $y_{\text {iast }}$ is a labor market outcome (described below) for individual $i$ of age $a$ living in state $s$ at time $t$. The term $D_{i t}^{\tau}$ represents a set of indicators for the 13 months before the pandemic (Jan 2019 - Jan 2020; $\sum_{\tau=-13}^{-1} \delta^{\tau} D_{i t}^{\tau}$ ) and 32 months during the pandemic (Mar 2020Oct 2022; $\sum_{\tau=1}^{32} \delta^{\tau} D_{i t}^{\tau}$ ), with Feb 2020 normalized to 0 . Equation 1 also includes the full set of interactions between each of the 12 calendar months and each of the 5 age dummies $\left(\gamma_{a t}\right)$ to control for differential seasonal patterns by age; state fixed effects $\left(\gamma_{s}\right)$; and a linear monthly time trend in time $\left(t_{t}\right)$ which is set to be unchanged after Feb 2020 to capture the slowdown of economic activity during the pandemic.

The individual controls $\left(X_{\text {iast }}\right)$ include dummy variables for: female, Black, other race/ethnicity, Hispanic origin, and metropolitan status (in central city and outside central city, with other as the baseline). The estimated coefficients $\delta^{1}-\delta^{32}$ capture the month-by-month effects of the pandemic — the difference in outcomes in each month during the pandemic relative to the corresponding month in prior years. For all models, we apply CPS person weights, and estimate robust standard errors with two-way clustering on state and year-month.

Next, we explore potential heterogeneity within young workers in (1) the year-by-year effects of the pandemic; and (2) the effects of early termination of pandemic UI programs on labor market outcomes. To do so, for each age group (15-19 and 20-24), we estimate Equation 2, in which we replace the month indicators with year indicators for 2020, 2021, and 2022. We also estimate Equation 3, which adds to the Equation 2 model a dummy variable that is set equal to one starting in the month after pandemic UI had been terminated in this state (zero otherwise).

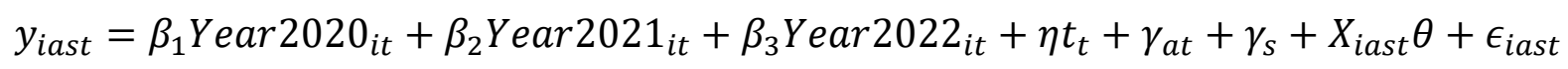




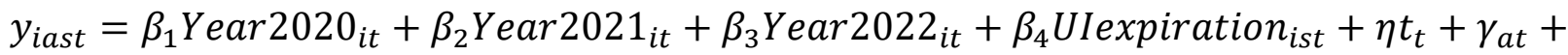

$$
\begin{aligned}
& \gamma_{s}+X_{\text {iast }} \theta+\epsilon_{\text {iast }}
\end{aligned}
$$

In Equations 2-3, Year 2020 is a 0-1 indicator for Mar 2020-Dec 2020; Year 2021 is a 0-1

indicator for the entire year of 2021; and Year 2022 is a 0-1 indicator for Jan 2022-October 2022.

The UI expiration variable is a $0-1$ indicator for the months after which state $s$ had terminated at

least one enhanced UI program (FPUC or PUA). ${ }^{2}$ We conduct several robustness checks of our

findings using Equation 3; results are discussed below.

As outcomes in our analysis, we consider usual work hours (all occupations), usual work hours by occupation, employed, employed full-time and employed part-time. The variable "usual work hours” captures hours usually worked per week at all jobs, or the number of hours worked last week if the respondent reports having a flexible work schedule (including zeros). We examine usual work hours in all occupations and usual work hours by the following three occupational categories: (1) food preparation and serving; (2) sales and related occupations; and (3) all other occupations. These occupational categories were selected because they are the largest occupational categories for young workers. ${ }^{3}$ The variable "employed" is an indicator for

\footnotetext{
${ }^{2}$ The termination month is set to June 2021 for Alabama, Alaska, Arkansas, Florida, Georgia, Idaho, Iowa, Mississippi, Missouri, Montana, Nebraska, New Hampshire, North Dakota, Ohio, Oklahoma, South Carolina, South Dakota, Texas, Utah, West Virginia and Wyoming, and July 2021 for Tennessee, Arizona and Louisiana. As Indiana and Maryland are ordered by a court to resume participation in enhanced UI programs, we set the termination month to be September 2021 for these two states and the remaining 24 states and DC (Congressional Research Service 2021).

${ }^{3}$ As of 2019, among employed 15-24-year-olds in the CPS, the two most common occupations were "food preparation and serving” and "sales and related.” Among 15-19-year-old workers in 2019, 27 and 21 percent reported food and sales occupations, respectively. Among 20-24-year-old workers in 2019, 20 and 17 percent reported food and sales occupations, respectively. Occupation is characterized based on the Census Bureau's 2010 occupation classification. A respondent is classified working in food preparation and serving occupations if his/her occupation code is between 4000-4150, and sales related occupations if the code is between 4700-4965, and other occupations if the code is outside of the abovementioned ranges.
} 
whether a respondent is at work in the preceding week. The variables "works full-time" and "works part-time" are based on the respondents' employment statuses.

In Appendix Table 1, we show summary statistics for the 15-19-year-old and the 20-24year-old samples. In the 15-19-year-old sample, 49 percent of respondents are female, 15 percent are Black, 23 percent are Hispanic, and 11 percent are classified as having other race/ethnicity. In the 15-19-year-old age group, 25 percent live in a central city, and 48 percent live outside a central city. These demographic characteristics are similar to those of the 20-24-year-old sample with a few exceptions. First, only 45 percent of the 20-24-year-old sample is female, probably because the samples are restricted to childless respondents without college education. Also, 2024-year-olds are more likely than 15-19-year-olds to be living in central cities.

As one would expect, 15-19-year-olds and 20-24-year-olds differ in their labor force attachment. Teenagers are much less likely than young adults to be employed full-time (6 percent for 15-19-year-olds vs. 36 percent for 20-24-year-olds), and they are much more likely than young adults to be currently enrolled in school (60 percent for 15-19-year-olds vs. 41 percent for 20-24-year-olds) (Appendix Table 1). In Appendix Table 2, we show employment rates, school enrollment rates, and employment rates in the month of July (when school is not in session) conditional on being enrolled in school in the month of April (when school is in session). The 15-19-year-old respondents' employment is, to some extent, more seasonal that that of 20-24-year-old respondents (although both age groups' outcomes show strong seasonality). For both age groups, full-time employment status is substantially higher in July vs. in April, but part-time employment status increases in July vs. April only for the 15-19-year-old sample. These seasonal effects are driven by respondents who are in school as of April (Appendix Table 2). 


\section{Results}

Figures 1 and 2 show the estimated coefficients on the month indicators in Equation 1 $\left(\delta^{\tau}\right)$. Figure 1 shows estimates from the model of work hours (in all occupations), while Figure 2 shows estimates from the employment model. In Appendix Figures 1-5, we show these figures for the remaining outcomes - work hours in food and serving occupations, work hours in sales and related occupations, work hours in other occupations, employed full-time, and employed part-time. As a group, these figures highlight the impact of the pandemic on work outcomes among 15-19-year-old and 20-24-year-old CPS respondents from January 2019 to October 2022.

Figure 1 shows that work hours (all occupations), which were stable in 2019, plunged by about 1.75 hours among 15-19-year-olds and by 6.89 hours among 20-24-year-olds in April 2020; these sudden drops represent about 30 and 32 percent decreases, respectively, evaluated at the pre-pandemic means (5.94 hours and 21.49 hours, Appendix Table 1). Work hours among 15-19-year-olds had returned to pre-pandemic norms by September 2020. In fact, by April 2021, work hours in the 15-19-year-old age group had started to exceed typical levels, often by about 10 percent, evaluated at the pre-pandemic mean. As of October 2022, work hours among 15-19year-olds were still 10 percent above their typical level.

Among 20-24-year-olds, although work hours (all occupations) steadily recovered from April 2020 until November 2020, progress started to lag at that point. Even in August 2021, work hours were still 2.1 hours below normal levels, which is about 10 percent lower than the pre-pandemic mean for the 20-24-year-old age group. We note that for 20-24-year-olds there appears to be a sharp, short-lived bounce back of overall work hours starting in September 2021, which coincides with the expiration of pandemic UI benefits in all states; we do not observe this 
bounce back among 15-19-year-olds. As of October 2022, work hours among 20-24-year-olds were at their typical pre-pandemic levels.

Figure 2 shows the same estimates, but for the model of employment. Along this margin, we see similar effects - as of April 2020, the pandemic had reduced employment by 11 percentage points (about 44 percent relative to the pre-pandemic mean) among 15-19-year-olds, and by 24 percentage points (about 38 percent relative to the pre-pandemic mean) among 20-24year-olds. In the younger age group, employment had recovered by September 2020, but in the older group, negative effects persisted until a temporary bounce back in October 2021. By January 2022, employment was once again persistently below pre-pandemic levels among 20-24year-olds. The persistent, negative effects of the pandemic on work outcomes among 20-24-yearolds appear to be driven by reductions in part-time employment (Appendix Figures 5). By October 2022, employment was back at pre-pandemic levels for 20-24-year-olds but was still about 8 percent higher among 15-19-year-olds relative to the pre-pandemic mean.

Table 1 shows estimates from Equation 2, in which we estimate the yearly effects of the pandemic on work hours and employment by age group (15-19, Panel A vs. 20-24, Panel B). The findings show that the pandemic had negative effects on work outcomes in both age groups, but among 15-19-year-olds, the negative effects occurred in 2020 only. Among 15-19-year-olds, the pandemic is associated with an 11 percent reduction in work hours (all occupations), a 17 percent reduction in full-time employment, and a 16 percent reduction in part-time employment in 2020; for the 20-24-year-old age group, these magnitudes were 17 percent, 22 percent, and 12 percent respectively (relative to the pre-pandemic means, Appendix Table 1).

By 2021, however, outcomes in the 15-19-year-old group had more than fully recovered, with work hours and employment levels persisting at higher-than-typical levels into 2022. For 
example, in 2021 and 2022, work hours (all occupations) were still 6-8 percent higher-thantypical for 15-19-year-olds (Panel A, Table 1). In contrast, in the 20-24-year-old age group, the pandemic's toll on work outcomes continued into 2021, with some outcomes still showing adverse effects in 2022. For example, as of 2022 among 20-24-year-olds, the pandemic is associated with a 17 percent reduction in work hours in food and serving occupations, a 3 percent decrease in any employment, and a 4 percent reduction in part-time employment.

This raises the question of pandemic UI, and whether teenagers returned to work more quickly than young adults because they were less likely to be eligible for benefits than young adults. From the findings in Table 2, we gain insight into this possibility by testing whether the expiration of pandemic UI benefits, which varied by state, had differing effects by age group. In Panel A, we show estimates of Equation 3 generated using the 15-19-year-old sample. These findings show that the expiration of pandemic UI programs has no statistically significant effects on outcomes except for work hours in sales occupations; expiration of pandemic UI programs is associated with (counter-intuitively) a 15 percent decrease in work hours in sales occupations, relative to pre-pandemic means. For the older age group (20-24), expiration of pandemic UI programs is associated with about a 6 percent increase in work hours (all occupations) and a 6 percent increase in full-time employment, relative to pre-pandemic means. These effects are driven by increases in work hours in the "other" occupation category.

In Table 3, we show findings from several robustness checks, based on the model shown in Table 2 (Equation 3). First, we consider the possible effects of pandemic-era CPS nonresponse bias on our findings. Ward \& Edwards (2021) provide evidence that the disruption and cessation of in-person interviewing during the pandemic affected the composition of the CPS sample in ways that the sampling weights do not adequately address. Specifically, it appears that the abrupt 
change in interviewing mode led to a shift in the CPS sample towards more advantaged individuals with greater-than-average attachment to the labor force. For our analysis, this finding may suggest that we are underestimating the negative effects of the pandemic on outcomes, if the most disadvantaged young workers have dropped out of the CPS sample.

To address this point, we estimate the work hours (all occupations) model limiting the samples to CPS respondents who could not be reached for their first or fifth Months-in-sample (MIS) interview, i.e., those who skipped MIS 1 interview but only responded between MIS 2-4 and those who skipped MIS 5 and only responded between MIS 6-8 (referred to as MIS2+). As discussed in Ward \& Edwards (2021), the MIS2+ group includes harder-to-reach and more disadvantaged individuals; thus, we may expect more harmful effects of the pandemic on their outcomes and a less robust rebound compared to estimates based on our main sample. In Table 3, columns 1-2, however, we see that the estimates for the MIS2+ group are similar to our main findings, with two exceptions. First, we no longer see the significantly increased work hours in 2021 and 2022 in the 15-19-year-old sample when we limit this sample to the MIS2+ subsample. Second, expiration of pandemic UI programs is not associated with a significant increase in work hours (all occupations) in the MIS2+ sample.

Next, as a robustness check, we include controls for monthly COVID-19 cases and deaths for each state as covariates in the models. At a 10\% significance level, COVID-19 deaths are negatively related to work hours among 15-19-year-olds, perhaps due to parents' fears about teenagers' exposure to the disease in the work setting. Including these covariates only sharpens our conclusions from the main findings; we see persistent negative effects of the pandemic on 20-24-year-olds; an improvement in work hours later in the pandemic for 15-19-year-olds; and 
an increase in work hours associated with early termination of pandemic UI programs for 20-24year-olds.

Finally, we explore whether the way in which we measured respondents’ ages affected our results. In the main analyses, we limit the samples to people aged 15-19 or 20-24 at the time of the CPS interview. Alternatively, the age group could be determined based on the respondent's age at the start time of the pandemic, and then respondents could be followed afterward. We try this alternative method, re-creating the samples by limiting them to respondents who were $15-19$ or 20-24 years old in $2020 .{ }^{4}$ After setting up the samples in this way, we re-estimated the "work hours (all occupations)” model shown in Table 2. This robustness check is shown in columns 5-8 of Table 3 . We show specifications with and without the age $\times$ month interactions because of the limited variation within age by month cells. Overall, the magnitudes of the estimates change somewhat, but the qualitative pattern of results is similar to that of our main findings.

Finally, in Appendix Table 3, we re-estimated the "usual work hours (all occupations)” model based on Equation 3 for three additional age groups - ages 25-54, 55-64, and 65-74. Columns 1-3 show findings for these age groups when samples are limited to childless respondents without college education, while columns 4-6 show estimates based on the samples for these age groups without such restrictions. We note that the pattern of findings for 25-54year-olds looks similar to that of the 20-24-year-old group in our study - the pandemic has persistent effects on work hours, and pandemic UI programs appear to have played a role.

\footnotetext{
${ }^{4}$ Because our samples are also limited to childless respondents without 4-year college degrees, the compositions of the samples can still change, even though we are now following the same cohorts over time. Also, this sample restriction leads to some of the younger cohorts having limited or no pre-periods; for example, if a respondent is aged 15 in 2020, we only observe this person's outcomes post-pandemic. In addition, in some cases, we lack variation in age by month cells - for example, we only observe people aged 26 in a single year (2022).
} 
Pandemic UI programs generally are not associated with work hours (all occupations) among workers aged 55 and older.

\section{Discussion and Conclusions}

Our findings show heterogeneity by age group in the effects of the pandemic among young, childless workers without college degrees. The youngest workers, aged 15-19, were more resilient than their 20-24-year-old counterparts. There was a brisk, full recovery in labor market outcomes among 15-19-year-olds. Among 20-24-year-olds, however, the recovery was sluggish, with work hours lagging below pre-pandemic norms, well into the year 2022.

Our findings support the idea that the heterogeneity by age group may be due in part to enhanced UI benefits, which were more accessible to 20-24-year-olds vs. 15-19-year-olds. Enhanced UI benefits may have made it possible for 20-24-year-old workers to turn down employment offers, perhaps to hold out for more favorable terms, or invest in education and training (Levitz, 2021), contributing to the tightness of the labor market. The heterogeneity may stem from other reasons as well. Fear of contagion may be a more pressing issue for 20-24-yearold workers, because they work more hours than 15-19-year-olds and are more likely to be living with non-relatives, and as a result have greater exposure to COVID-19. In addition, 20-24-yearold workers have more experience than 15-19-year-old workers and thus may have jobs that involve more person-to-person contact and greater COVID-19 exposure risk.

Fear of contagion is likely to have been an important factor in the initial waves of the pandemic, when vaccinations were not widely available, and disease was relatively severe. With widespread vaccination, fear of contagion may have been less of a concern for workers by the second half of 2021. The expiration of enhanced UI benefits in all states in September 2021, 
therefore, may have induced 20-24-year-old workers to return to their pre-pandemic work hours in this month; our findings are consistent with this story.

Our study has important limitations. First, non-response bias during the pandemic may have affected our findings in ways that our simple robustness check does not capture. We may be under-stating the negative effects of the pandemic and over-stating the recovery if the most disadvantaged workers left the CPS sample during the pandemic, and if the sampling design does not adequately address this issue. Second, states and localities may have implemented other policies that coincided with the termination of pandemic UI programs, and these unmeasured factors may have affected our estimates of the effects of termination on work outcomes.

As of December 2022, COVID-19 continues to chart an unpredictable course throughout the world. In this challenging environment, it is critical to inform policymakers by estimating the impact of the pandemic on young workers, and by exploring heterogenous effects within this group. Future research should address these longer-term effects of the pandemic on young workers' human capital and labor market outcomes. 


\section{References}

1. Aaronson, S. \& Alba, F. (April 15, 2020). “The unemployment impacts of COVID-19: lessons from the Great Recession.” Available at: The unemployment impacts of COVID19: lessons from the Great Recession (brookings.edu). Accessed 9/9/21.

2. Alon, T.M., Doepke, M., Rumsey-Olmstead, J., \& Tertilt, M. (April 2020). The impact of COVID-19 on gender equality. NBER working paper 26947. Available at: http://www.nber.org/papers/w26947.

3. Alon, T.M., Coskun, S., Doepke, M., Koll, D. \& Tertlit, M. (2021). “From mancession to shecession: Women’s employment in regular and pandemic recessions.” NBER Macroeconomics Annual, 36 (Eds. Eichenbaum \& Hurst).

4. Altonji, J., Contractor, Z., Finamor, L., Haygood, R., Lindenlaub, I., Meghir, C., O’Dea, C., Scott, D., Wang, L., \& Washington, E. (July 14, 2020). “Employment effects of unemployment insurance generosity during the pandemic.” Available at: https://tobin.yale.edu/sites/default/files/files/C-19\%20Articles/CARESUI_identification_vF\%281\%29.pdf, Accessed 5/22.

5. Baker, S.R., Farroknhia, R.A., Meyer, S., Pagel, M., \& Yannelis, C. (July 21 2020). “How does household spending respond to an epidemic? Consumption during the 2020 COVID-19 pandemic.” Rev Asset Pricing Stud..

6. Bartik, A.W., Bertrand, M., Lin, F., Rothstein, J. \& Unrath, M. (2020). "Measuring the Labor Market at the Onset of the COVID-19 Crisis," Brookings Papers on Economic Activity, vol 2020(2), pages 239-268. 
7. Borjas, G.J. \& Cassidy, H. (2020). “The adverse effect of the COVID-19 labor market shock on immigrant employment.” NBER working paper 27243.

8. Bureau of Economic Analysis (BEA), "How will the expansion of unemployment benefits in response to the COVID-19 pandemic be recorded in the NIPAS?” Available at: https://www.bea.gov/help/faq/1415, Accessed 9/10/21.

9. Center on Budget and Policy Priorities (CBPP), Chart book: Tracking the recovery from the pandemic recession. Available at: https://www.cbpp.org/research/economy/trackingthe-recovery-from-the-pandemic-recession. Accessed 12/22.

10. Congressional Research Service (2021) States Opting Out of COVID-19 Unemployment Insurance (UI) Agreements IN11679. Last updated August 20, 2021.

11. Coombs, K., Dube, A., Jahnke, C., Kluender, R., Naidu, S., \& Stepner, M. (August 20, 2021). "Early withdrawal of pandemic unemployment insurance: Effects on earnings, employment, and consumption.” Working paper.

12. Dube, Arindrajit. (August 20, 2021). "Early withdrawal of pandemic UI: impact on job finding in July using Current Population Survey.” Available at: https://arindube.com/blog-posts/. Accessed 9/9/21.

13. Falk, G., Romero, P.D., Carter, J.A., Nicchitta, I.A., \& Nyhof, E.C. (June 15, 2021). “Unemployment rates during the COVID-19 pandemic,” Congressional Research Service Report 46554, Available at: https://crsreports.congress.gov/. Accessed 9/21.

14. Finamor, L. \& Scott, D. "Labor market trends and unemployment insurance generosity during the pandemic.” Economics Letters 199. 
15. Flood, S. King, M., Rodgers, R., Ruggles, R., Warren, J.R. and Westberry, M. (2022) Integrated Public Use Microdata Series, Current Population Survey: Version 10.0 [dataset]. Minneapolis, MN: IPUMS.

16. Forsythe, E. (2021). “Why don’t firms hire young workers during recessions?” The Economic Journal 132: 1765-1789.

17. Ganong, P., Greig, F., Liebeskind, M., Noel, P. Sullivan, D.M. \& and Vavra, J. (February 2021a). “Spending and Job Search Impacts of Expanded Unemployment Benefits: Evidence from Administrative Micro Data.” Becker Friedman Institute for Economics Working Paper 2021-19.

18. Ganong, P., Greig, F., Noel, P., Sullivan, D.M. \& Vavra, J. (July 29, 2021b). “Micro and macro disincentive effects of expanded unemployment benefits.” Working paper.

19. Glatt, J. \& Wunnava, P. (2018). “Help Not Wanted: The Dismal Science of Youth Unemployment’s Scarring Effect.” iBusiness, 10, 51-84. Available at: http://www.scirp.org/journal/ib.

20. Goda Shah, G., Jackson, E., Nicholas, L.H. \& Stith, S.S. (2021). “The impact of COVID19 on older workers’ employment and social security spillovers.” NBER working paper 29083.

21. Gopinath, G. (April 2020). Limiting the economic fallout of the coronavirus with large targeted policies in Mitigating the COVID-19 Crisis - Act Fast and Do Whatever it Takes.

22. Handwerker, E.W., Meyer, P.B. \& Piacentini, J. (December 2020). “Employment recovery in the wake of the COVID-19 recession.” US Bureau of Labor Statistics 
Monthly Labor Review, Available at:

https://www.bls.gov/opub/mlr/2020/article/employment-recovery.htm; Accessed 9/2021.

23. Holzer, H.J., Hubbard, R.G. \& Strain, M.R. (December 2021). “Did pandemic unemployment benefits reduce employment? Evidence from early state-level expirations in June 2021.” NBER Working Paper 29575.

24. Hoynes, H., Miller, D.L. \& Schaller, J. (Summer 2012). “Who suffers during recessions?” Journal of Economic Perspectives 26:3, 27-48.

25. Kalenkoski, C.M. \& Pabilonia, S. W. (2012). “Time to work or time to play: The effect of student employment on homework, sleep, and screen time.” Labour Economics, 19, 211-221.

26. Kochhar, R. \& Barroso, A. (March 20, 2020). "Young workers likely to be hard hit as COVID-19 strikes a blow to restaurants and other service sector jobs.” Pew Research Center, Available at: https://www.pewresearch.org/fact-tank/2020/03/27/young-workerslikely-to-be-hard-hit-as-COVID-19 -strikes-a-blow-to-restaurants-and-other-servicesector-jobs/. Accessed 9/9/21.

27. Lee, S.Y., Park, M. \& Shin, Y. (2021). "Hit harder, recover slower? Unequal employment effects of the COVID-19 shock.” NBER working paper 28354.

28. Leos-Urbel, J. (2014). "What Is a Summer Job Worth? The Impact of Summer Youth Employment on Academic Outcomes.” Journal of Policy Analysis and Management Vol. 33, No. 4, pp. 891-911

29. Levitz, E. (May 7, 2021). “5 Explanations for April’s Bad Jobs Report.” Available at: https://nymag.com/intelligencer/2021/05/jobs-report-explained-ui-childcare-seasonaladjustment.html. Accessed: 9/10/21. 
30. Marinescu, I., Skandalis, D. \& Zhao, D. (2021). "The impact of the Federal Pandemic Unemployment Compensation on job search and vacancy creation," Journal of Public Economics, Elsevier, vol. 200(C).

31. Mishory, J. \& Stettner, A. (April 23, 2020). "Unemployment insurance and young people in the wake of COVID-19.” The Century Foundation. Available at: Unemployment Insurance and Young People in the Wake of COVID-19 (tcf.org); Accessed 9/21.

32. New York State Department of Labor (NYS DOL), “Coronavirus aid, relief, and economoc security (CARES) act.” Available at: https://dol.ny.gov/coronavirus-aid-reliefand-economic-security-cares-act. Accessed 9/21.

33. Oreopoulos, P., von Wachter, T. \& Heisz, A. (2012). "The short- and long-term career effects of graduating in a recession.” AEJ: Applied Economics Vol. 4 No. 1: 1-29.

34. Petrosky-Nadeau, Nicolas, Robert G. Valletta. 2021 “UI Generosity and Job Acceptance: Effects of the 2020 CARES Act,” Federal Reserve Bank of San Francisco Working Paper 2021-13. https://doi.org/10.24148/wp2021-13.

35. Rothstein, D.S. (2007). "High School Employment and Youths' Academic Achievement.” The Journal of Human Resources, Vol. 42, No. 1 pp. 194-213.

36. Santarosa, R. (August 21, 2013). “Long-term consequences of youth unemployment.” US Chamber of Commerce Foundation. Available at: https://www.uschamberfoundation.org/blog/post/long-term-consequences-youthunemployment/34032. Accessed 5/22.

37. Tyler, J.H. (2003). "Using State Child Labor Laws to Identify the Effect of School-Year Work on High School Achievement.” Journal of Labor Economics, Vol. 21, No. 2, pp. 381-408. 
38. Ward, J.M. \& Edwards, K.A. (2021). “CPS nonresponse during the COVID-19 pandemic: Explanations, extent and effect.” Labour Economics, Vol. 72, 1020-60. 
Table 1: Effect of pandemic on labor market outcomes

\begin{tabular}{|c|c|c|c|c|c|c|c|}
\hline \multicolumn{8}{|c|}{ Panel A: $15-19$ age group } \\
\hline & \multicolumn{4}{|c|}{ Usual Work Hours } & \multicolumn{3}{|c|}{ Employment } \\
\hline & All occ. & Food & Sales & Other & Any & Full-time & Part-time \\
\hline & $(1)$ & $(2)$ & (3) & (4) & (5) & (6) & (7) \\
\hline \multirow[t]{2}{*}{ Year 2020} & $-0.65 * * *$ & $-0.22 * *$ & -0.11 & $-0.32 * * *$ & $-0.04 * * *$ & $-0.01 * * *$ & $-0.03 * * *$ \\
\hline & $(0.22)$ & $(0.08)$ & $(0.07)$ & $(0.12)$ & $(0.01)$ & $(0.00)$ & $(0.01)$ \\
\hline \multirow[t]{2}{*}{ Year 2021} & $0.38 * *$ & $0.18^{* *}$ & -0.03 & $0.23 * *$ & 0.01 & $0.00 *$ & 0.00 \\
\hline & $(0.16)$ & $(0.08)$ & $(0.06)$ & $(0.11)$ & $(0.01)$ & $(0.00)$ & $(0.00)$ \\
\hline \multirow[t]{2}{*}{ Year 2022} & $0.47^{* * *}$ & $0.17^{* * *}$ & 0.00 & $0.30 * * *$ & $0.02 * * *$ & 0.00 & $0.01 * * *$ \\
\hline & $(0.15)$ & $(0.06)$ & $(0.05)$ & $(0.10)$ & $(0.00)$ & $(0.00)$ & $(0.00)$ \\
\hline Y2020=Y2021 & 0.00 & 0.00 & 0.21 & 0.00 & 0.00 & 0.00 & 0.00 \\
\hline Y2020=Y2022 & 0.00 & 0.00 & 0.18 & 0.00 & 0.00 & 0.00 & 0.00 \\
\hline Y2021=Y2022 & 0.49 & 0.82 & 0.62 & 0.49 & 0.07 & 0.54 & 0.03 \\
\hline \multicolumn{8}{|c|}{ Panel B: $20-24$ age group } \\
\hline & \multicolumn{4}{|c|}{ Usual Work Hours } & \multicolumn{3}{|c|}{ Employment } \\
\hline & All occ. & Food & Sales & Other & Any & Full-time & Part-time \\
\hline & $(1)$ & $(2)$ & (3) & (4) & $(5)$ & (6) & (7) \\
\hline \multirow[t]{2}{*}{ Year 2020} & $-3.68 * * *$ & $-1.00 * * *$ & $-0.29 * *$ & $-2.38 * * *$ & $-0.11 * * *$ & $-0.08 * * *$ & $-0.03 * * *$ \\
\hline & $(0.56)$ & $(0.13)$ & $(0.13)$ & $(0.40)$ & $(0.02)$ & $(0.01)$ & $(0.01)$ \\
\hline \multirow[t]{2}{*}{ Year 2021} & $-1.09 * * *$ & $-0.54 * * *$ & -0.08 & -0.48 & $-0.04 * * *$ & $-0.02 * * *$ & $-0.02 * * *$ \\
\hline & $(0.34)$ & $(0.11)$ & $(0.11)$ & $(0.37)$ & $(0.01)$ & $(0.01)$ & $(0.01)$ \\
\hline \multirow[t]{2}{*}{ Year 2022} & -0.40 & $-0.52 * * *$ & -0.17 & 0.29 & $-0.02 * *$ & -0.01 & $-0.01 * * *$ \\
\hline & $(0.33)$ & $(0.12)$ & $(0.16)$ & $(0.40)$ & $(0.01)$ & $(0.01)$ & $(0.00)$ \\
\hline Y2020=Y2021 & 0.00 & 0.00 & 0.11 & 0.00 & 0.00 & 0.00 & 0.19 \\
\hline Y2020=Y2022 & 0.00 & 0.00 & 0.45 & 0.00 & 0.00 & 0.00 & 0.11 \\
\hline $\mathrm{Y} 2021=\mathrm{Y} 2022$ & 0.02 & 0.88 & 0.44 & 0.01 & 0.00 & 0.04 & 0.45 \\
\hline
\end{tabular}

Note: ${ }^{* * *} \mathrm{p}<0.01,{ }^{* *} \mathrm{p}<0.05,{ }^{*} \mathrm{p}<0.1$. Table presents estimates of $\beta$ s from equation (2). The number of observations is 560,397 for Panel A and 360,175 for Panel B. Year 2020 is a 0-1 indicator for Mar 2020Dec 2020. Year 2021 is a 0-1 indicator for the entire year of 2021. Year 2022 is a 0-1 indicator for Jan 2022-Oct 2022. The last three rows report the T-test for equality of the estimated coefficients for two years. 
Table 2: Effect of terminating enhanced UI benefits

\begin{tabular}{|c|c|c|c|c|c|c|c|}
\hline \multicolumn{8}{|c|}{ Panel A: $15-19$ age group } \\
\hline & \multicolumn{4}{|c|}{ Usual Work Hour } & \multicolumn{3}{|c|}{ Employment } \\
\hline & All occ. & Food & Sales & Other & Any & Full-time & Part-time \\
\hline & $(1)$ & $(2)$ & (3) & $(4)$ & (5) & $(6)$ & (7) \\
\hline \multirow[t]{2}{*}{ Year 2020} & $-0.65^{* * *}$ & $-0.22 * *$ & -0.11 & $-0.32 * * *$ & $-0.04 * * *$ & $-0.01 * * *$ & $-0.03 * * *$ \\
\hline & $(0.21)$ & $(0.08)$ & $(0.07)$ & $(0.12)$ & $(0.01)$ & $(0.00)$ & $(0.01)$ \\
\hline \multirow{2}{*}{ Year 2021} & $0.46 * *$ & $0.23 * *$ & 0.03 & $0.20^{*}$ & 0.01 & $0.01^{* *}$ & 0.00 \\
\hline & $(0.17)$ & $(0.10)$ & $(0.06)$ & $(0.11)$ & $(0.01)$ & $(0.00)$ & $(0.01)$ \\
\hline \multirow[t]{2}{*}{ Year 2022} & $0.69 * * *$ & $0.30 * *$ & $0.18 * *$ & 0.20 & $0.02 * *$ & $0.01^{* *}$ & $0.02 *$ \\
\hline & $(0.19)$ & $(0.11)$ & $(0.07)$ & $(0.16)$ & $(0.01)$ & $(0.00)$ & $(0.01)$ \\
\hline \multirow[t]{2}{*}{ UI Expiration } & -0.21 & -0.13 & $-0.18 * *$ & 0.09 & -0.01 & -0.00 & -0.00 \\
\hline & $(0.16)$ & $(0.08)$ & $(0.07)$ & $(0.16)$ & $(0.01)$ & $(0.00)$ & $(0.01)$ \\
\hline Y2020=Y2021 & 0.00 & 0.00 & 0.03 & 0.00 & 0.00 & 0.00 & 0.00 \\
\hline Y2020=Y2022 & 0.00 & 0.00 & 0.00 & 0.01 & 0.00 & 0.00 & 0.00 \\
\hline Y2021=Y2022 & 0.06 & 0.18 & 0.02 & 0.96 & 0.04 & 0.86 & 0.02 \\
\hline \multicolumn{8}{|c|}{ Panel B: $20-24$ age group } \\
\hline & \multicolumn{4}{|c|}{ Usual Work Hour } & \multicolumn{3}{|c|}{ Employment } \\
\hline & All occ. & Food & Sales & Other & Any & Full-time & Part-time \\
\hline & $(1)$ & $(2)$ & (3) & $(4)$ & (5) & $(6)$ & (7) \\
\hline \multirow[t]{2}{*}{ Year 2020} & $-3.68 * * *$ & $-1.00 * * *$ & $-0.29 * *$ & $-2.38 * * *$ & $-0.11 * * *$ & $-0.08 * * *$ & $-0.03 * * *$ \\
\hline & $(0.57)$ & $(0.13)$ & $(0.13)$ & $(0.41)$ & $(0.02)$ & $(0.01)$ & $(0.01)$ \\
\hline \multirow[t]{2}{*}{ Year 2021} & $-1.55^{* * *}$ & $-0.63 * * *$ & -0.06 & $-0.86 * *$ & $-0.05 * * *$ & $-0.03 * * *$ & $-0.02 * * *$ \\
\hline & $(0.33)$ & $(0.13)$ & $(0.12)$ & $(0.34)$ & $(0.01)$ & $(0.01)$ & $(0.01)$ \\
\hline \multirow[t]{2}{*}{ Year 2022} & $-1.70 * * *$ & $-0.78 * * *$ & -0.13 & $-0.79 *$ & $-0.05 * * *$ & $-0.03 * *$ & -0.01 \\
\hline & $(0.54)$ & $(0.23)$ & $(0.23)$ & $(0.46)$ & $(0.02)$ & $(0.01)$ & $(0.01)$ \\
\hline \multirow[t]{2}{*}{ UI Expiration } & $1.25 * *$ & 0.25 & -0.04 & $1.04 * *$ & 0.02 & $0.02 * *$ & 0.00 \\
\hline & $(0.50)$ & $(0.22)$ & $(0.16)$ & $(0.40)$ & $(0.01)$ & $(0.01)$ & $(0.01)$ \\
\hline$Y 2020=Y 2021$ & 0.00 & 0.02 & 0.13 & 0.00 & 0.00 & 0.00 & 0.25 \\
\hline Y2020=Y2022 & 0.01 & 0.35 & 0.51 & 0.01 & 0.01 & 0.00 & 0.29 \\
\hline Y2021=Y2022 & 0.68 & 0.35 & 0.68 & 0.83 & 0.62 & 0.90 & 0.63 \\
\hline
\end{tabular}

Note: ${ }^{* * *} \mathrm{p}<0.01,{ }^{* *} \mathrm{p}<0.05,{ }^{*} \mathrm{p}<0.1$. Table presents estimates of $\beta$ s from equation (3). The number of observations is 560,397 for Panel A and 360,175 for Panel B. Year 2020 is a 0-1 indicator for Mar 2020Dec 2020. Year 2021 is a 0-1 indicator for the entire year of 2021. Year 2022 is a 0-1 indicator for Jan 2022-Oct 2022. The last three rows report the T-test for equality of the estimated coefficients for two years. 
Table 3: Robustness checks

\begin{tabular}{|c|c|c|c|c|c|c|c|c|}
\hline \multicolumn{9}{|c|}{ Usual Work Hour } \\
\hline & \multicolumn{2}{|c|}{ MIS 2+ sample } & \multicolumn{2}{|c|}{ + Covid controls } & \multicolumn{4}{|c|}{ Define age group using age in 2020} \\
\hline & & & & & \multicolumn{2}{|c|}{ w/o age $\times$ month } & \multicolumn{2}{|c|}{ w. age $\times$ month } \\
\hline & $15-19$ & $20-24$ & $15-19$ & $20-24$ & $15-19$ & $20-24$ & $15-19$ & $20-24$ \\
\hline & $(1)$ & $(2)$ & (3) & (4) & (5) & $(6)$ & (7) & (8) \\
\hline \multirow[t]{2}{*}{ Year 2020} & $-0.66^{*}$ & $-4.72 * * *$ & $-0.59 * * *$ & $-3.76 * * *$ & $-0.41 * *$ & $-3.42 * * *$ & $-0.51 * * *$ & $-3.48 * * *$ \\
\hline & $(0.36)$ & $(0.91)$ & $(0.21)$ & $(0.60)$ & $(0.17)$ & $(0.56)$ & $(0.17)$ & $(0.50)$ \\
\hline \multirow[t]{2}{*}{ Year 2021} & 0.09 & $-1.21 *$ & $0.52 * * *$ & $-1.63 * * *$ & $0.70 * *$ & $-1.56 * * *$ & $0.71 * * *$ & $-1.43 * * *$ \\
\hline & $(0.34)$ & $(0.64)$ & $(0.18)$ & $(0.33)$ & $(0.27)$ & $(0.34)$ & $(0.21)$ & $(0.35)$ \\
\hline \multirow[t]{2}{*}{ Year 2022} & 0.04 & $-1.97 * *$ & $0.70 * * *$ & $-1.83 * * *$ & $1.08 * * *$ & $-1.81 * * *$ & $1.35 * * *$ & $-1.18 * *$ \\
\hline & $(0.56)$ & $(0.94)$ & $(0.18)$ & $(0.52)$ & $(0.37)$ & $(0.53)$ & $(0.31)$ & $(0.57)$ \\
\hline \multirow[t]{2}{*}{ UI Expiration } & 0.20 & 0.52 & -0.21 & $1.18^{* *}$ & -0.06 & $1.49 * * *$ & -0.36 & $0.99 * *$ \\
\hline & $(0.41)$ & $(0.66)$ & $(0.16)$ & $(0.53)$ & $(0.30)$ & $(0.39)$ & $(0.28)$ & $(0.48)$ \\
\hline \multirow[t]{2}{*}{ Covid case } & & & 0.09 & 0.53 & & & & \\
\hline & & & $(0.11)$ & $(0.39)$ & & & & \\
\hline \multirow[t]{2}{*}{ Covid death } & & & $-22.08 *$ & -13.41 & & & & \\
\hline & & & $(12.30)$ & $(27.07)$ & & & & \\
\hline$Y 2020=Y 2021$ & 0.02 & 0.00 & 0.00 & 0.00 & 0.00 & 0.00 & 0.00 & 0.00 \\
\hline$Y 2020=Y 2022$ & 0.13 & 0.02 & 0.00 & 0.02 & 0.00 & 0.03 & 0.00 & 0.00 \\
\hline Y2021=Y2022 & 0.89 & 0.21 & 0.15 & 0.61 & 0.13 & 0.53 & 0.00 & 0.54 \\
\hline Obs & 60906 & 50620 & 560397 & 360175 & 454649 & 416060 & 454649 & 416060 \\
\hline
\end{tabular}

Note: *** $\mathrm{p}<0.01, * * \mathrm{p}<0.05$, $* \mathrm{p}<0.1$. Table presents estimates of $\beta$ s from equation (3). Year 2020 is a 0 1 indicator for Mar 2020-Dec 2020. Year 2021 is a 0-1 indicator for the entire year of 2021. Year 2022 is a 0-1 indicator for Jan 2022-Oct 2022. The last three rows report the T-test for equality of the estimated coefficients for two years. COVID case (death) records monthly rate of COVID cases (death) per 1000 population in the state and are from the Johns Hopkins Coronavirus Resource Center. The pre-pandemic average usual working hour is 6.50 for 15-19 MIS 2+ sample (column 1) and 22.81 for 20-24 MIS 2+ sample (column 2). 


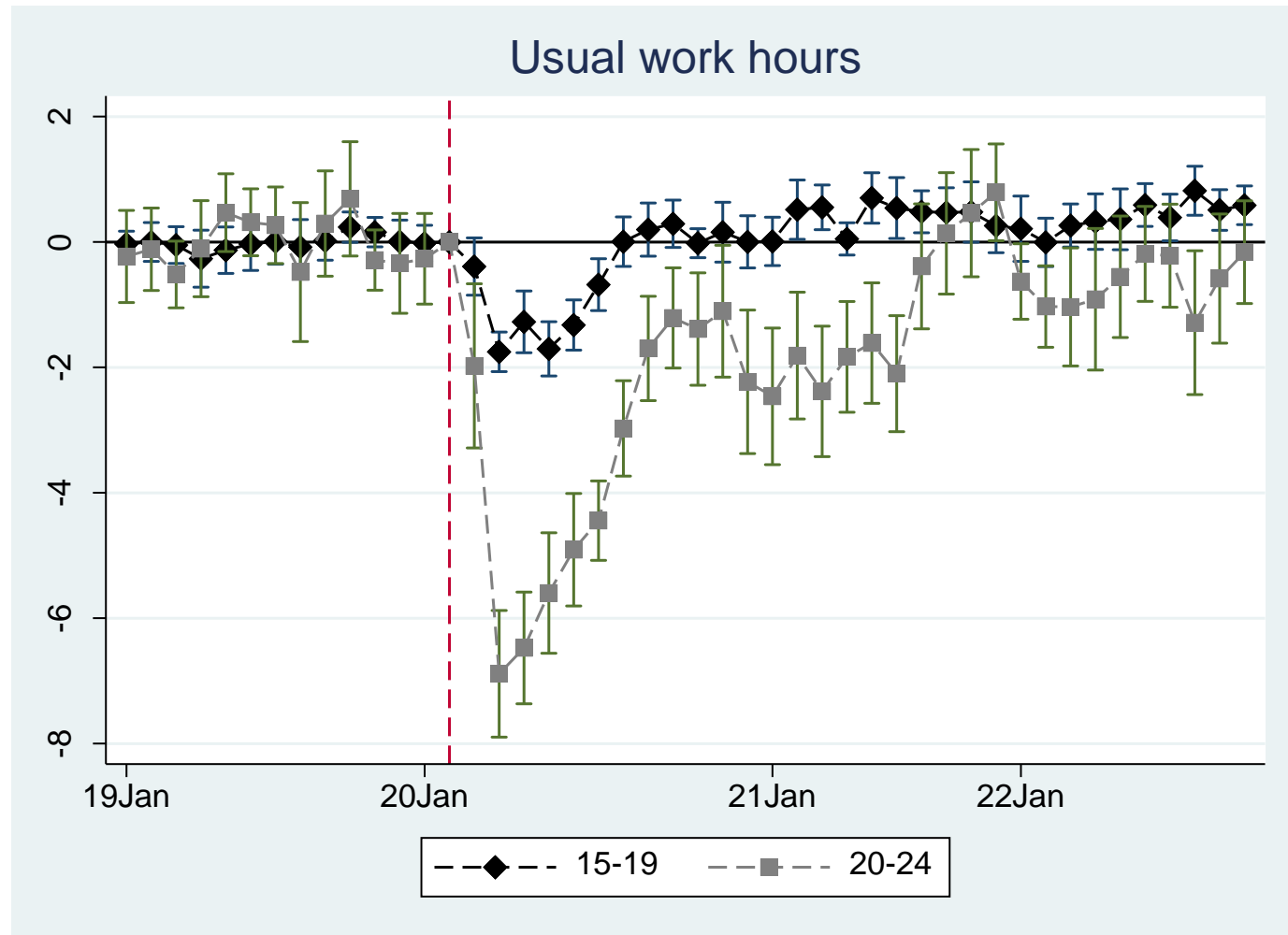

Figure 1:

Effect of the pandemic on usual work hours

Note: Figure shows estimated coefficients and 95\% CIs on month indicators in Eq. 1. 


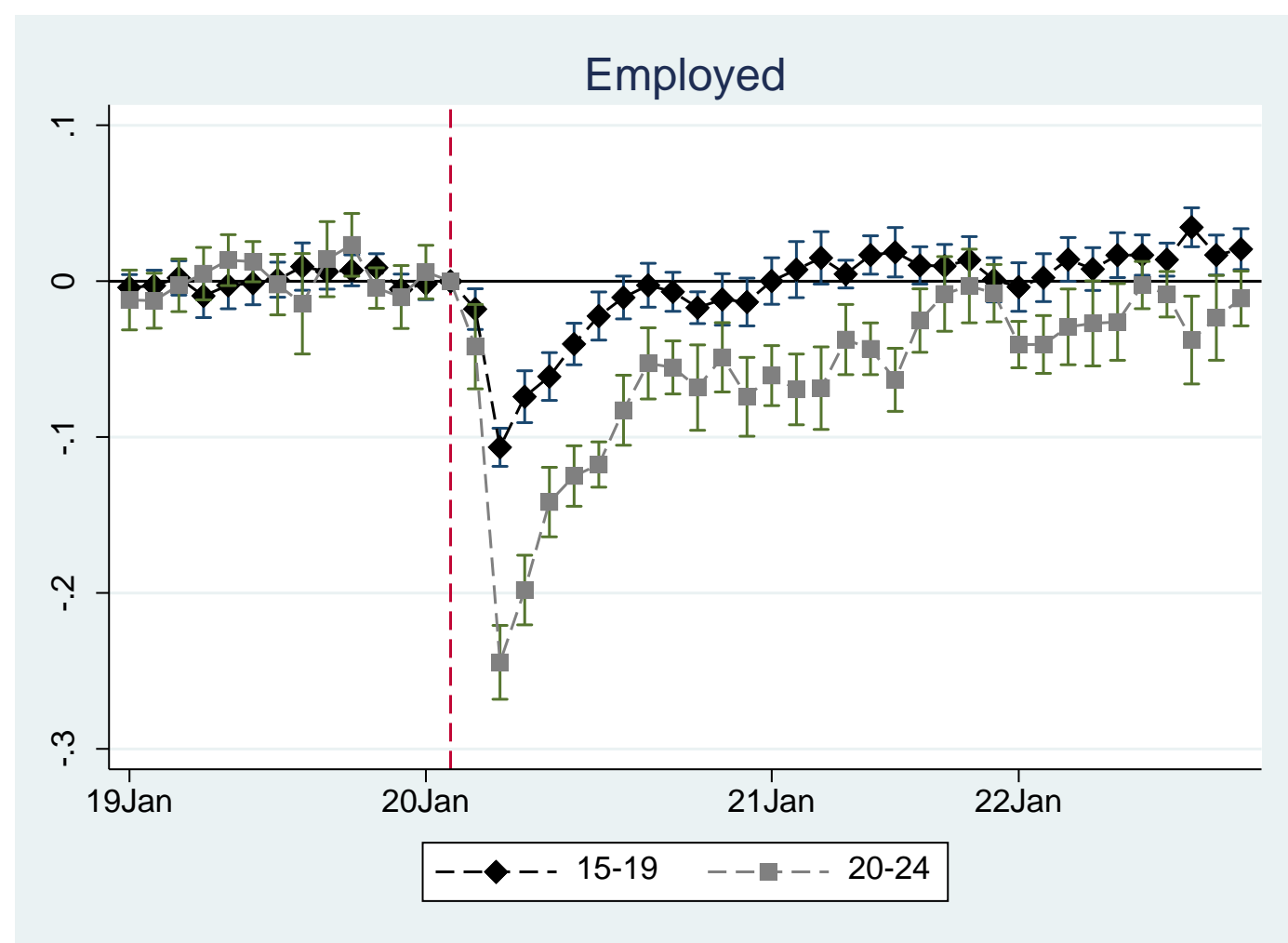

Figure 2:

Effect of the pandemic on employment

Note: Figure shows estimated coefficients and 95\% CIs on month indicators in Eq. 1. 
Appendix Table 1: Summary Statistics

\begin{tabular}{|c|c|c|c|c|c|c|}
\hline \multirow[t]{2}{*}{ Age group: } & \multicolumn{3}{|c|}{$15-19$} & \multicolumn{3}{|c|}{$20-24$} \\
\hline & $(1)$ & $(2)$ & $(3)$ & $(4)$ & $(5)$ & $(6)$ \\
\hline & All & Before & After & All & Before & After \\
\hline Age & 16.92 & 16.92 & 16.92 & 21.68 & 21.70 & 21.65 \\
\hline Female & 0.49 & 0.49 & 0.49 & 0.45 & 0.45 & 0.46 \\
\hline Black & 0.15 & 0.15 & 0.15 & 0.16 & 0.16 & 0.16 \\
\hline Other race & 0.11 & 0.11 & 0.12 & 0.10 & 0.10 & 0.10 \\
\hline Hispanic & 0.23 & 0.22 & 0.24 & 0.21 & 0.21 & 0.22 \\
\hline In central city & 0.25 & 0.25 & 0.25 & 0.30 & 0.30 & 0.29 \\
\hline Outside central city & 0.48 & 0.48 & 0.48 & 0.44 & 0.44 & 0.44 \\
\hline Hours, all occupations & 6.11 & 5.94 & 6.38 & 21.09 & 21.49 & 20.45 \\
\hline $\begin{array}{l}\text {-Food preparation and } \\
\text { serving }\end{array}$ & 1.54 & 1.48 & 1.63 & 2.76 & 3.00 & 2.37 \\
\hline -Sales and related & 1.20 & 1.23 & 1.17 & 2.99 & 3.13 & 2.78 \\
\hline -Other occupations & 3.37 & 3.24 & 3.57 & 15.34 & 15.37 & 15.29 \\
\hline Employment rate & 0.25 & 0.25 & 0.25 & 0.61 & 0.63 & 0.58 \\
\hline Work full-time & 0.06 & 0.06 & 0.07 & 0.36 & 0.36 & 0.35 \\
\hline Work part-time & 0.19 & 0.19 & 0.19 & 0.25 & 0.26 & 0.24 \\
\hline School attendance & 0.60 & 0.61 & 0.59 & 0.41 & 0.42 & 0.39 \\
\hline Obs & 560397 & 368450 & 191947 & 360175 & 237084 & 123091 \\
\hline
\end{tabular}

Note: Data come from the CPS, 2016 Jan-2022 Oct, with 2016 Jan-2020 Feb being the before-pandemic time period, and 2020 Mar-2022 Oct being the after-pandemic time period. 
Appendix Table 2: Full-time and Part-time status by school attendance

\begin{tabular}{|c|c|c|c|c|}
\hline Month & \multicolumn{2}{|c|}{ April of 2016-2019 } & \multicolumn{2}{|c|}{ July of 2016-2019 } \\
\hline Age group & $15-19$ & $20-24$ & $15-19$ & $20-24$ \\
\hline & $(1)$ & $(2)$ & (3) & $(4)$ \\
\hline April in school & $67 \%$ & $46 \%$ & $68 \%$ & $46 \%$ \\
\hline Full-time status & $5 \%$ & $34 \%$ & $9 \%$ & $41 \%$ \\
\hline Part-time status & $18 \%$ & $28 \%$ & $21 \%$ & $25 \%$ \\
\hline Full-time|April in school & $2 \%$ & $10 \%$ & $9 \%$ & $26 \%$ \\
\hline Part-time|April in school & $21 \%$ & $37 \%$ & $25 \%$ & $33 \%$ \\
\hline Full-time|April out school & $11 \%$ & $54 \%$ & $10 \%$ & $53 \%$ \\
\hline Part-time|April out school & $12 \%$ & $21 \%$ & $11 \%$ & $18 \%$ \\
\hline Obs & 29687 & 19606 & 6147 & 3810 \\
\hline
\end{tabular}

Note: The statistics for July are based on a subsample who are observed in April of the same year. 
Appendix Table 3: Effects of the pandemic on other age groups

\begin{tabular}{|l|l|l|l|l|l|l|}
\hline & \multicolumn{7}{|c|}{ Usual Work Hours } \\
\hline & \multicolumn{2}{|c|}{ Childless, no college degree } & \multicolumn{1}{c|}{ all } \\
\hline & $25-54$ & $55-64$ & $65-74$ & \multicolumn{1}{|c|}{$25-54$} & \multicolumn{1}{|c|}{$55-64$} & \multicolumn{1}{|c|}{$65-74$} \\
\hline & $(1)$ & $(2)$ & $(3)$ & $(4)$ & $(5)$ & $(6)$ \\
\hline Year 2020 & $-3.52^{* * *}$ & $-1.58^{* * *}$ & $-0.83^{* * *}$ & $-2.64 * * *$ & $-1.77^{* * *}$ & $-0.87^{* * *}$ \\
\hline & $(0.44)$ & $(0.29)$ & $(0.16)$ & $(0.31)$ & $(0.23)$ & $(0.14)$ \\
\hline Year 2021 & $-2.53^{* * *}$ & $-1.39 * * *$ & $-0.61^{* * *}$ & $-1.77^{* * *}$ & $-1.06^{* * *}$ & $-0.78^{* * *}$ \\
\hline & $(0.28)$ & $(0.24)$ & $(0.16)$ & $(0.14)$ & $(0.13)$ & $(0.14)$ \\
\hline Year 2022 & $-2.16^{* * *}$ & $-0.84^{* *}$ & -0.49 & $-1.19 * * *$ & $-0.59 * *$ & $-0.63^{* *}$ \\
\hline & $(0.31)$ & $(0.41)$ & $(0.30)$ & $(0.17)$ & $(0.23)$ & $(0.27)$ \\
\hline UI Expiration & $1.24^{* * *}$ & 0.31 & 0.12 & $0.70^{* * *}$ & $0.36^{*}$ & 0.27 \\
\hline & $(0.25)$ & $(0.27)$ & $(0.22)$ & $(0.13)$ & $(0.18)$ & $(0.20)$ \\
\hline Y2020=Y2021 & 0.03 & 0.55 & 0.22 & 0.01 & 0.01 & 0.56 \\
\hline Y2020=Y2022 & 0.01 & 0.15 & 0.33 & 0.00 & 0.00 & 0.46 \\
\hline Y2021=Y2022 & 0.05 & 0.08 & 0.60 & 0.00 & 0.01 & 0.49 \\
\hline Obs & 909854 & 629445 & 565765 & 3253047 & 1255804 & 1019358 \\
\hline Pre-pandemic mean & 29.26 & 21.96 & 7.21 & 32.75 & 25.35 & 9.03 \\
\hline
\end{tabular}

Note: ${ }^{* * *} \mathrm{p}<0.01,{ }^{* *} \mathrm{p}<0.05,{ }^{*} \mathrm{p}<0.1$. Table presents estimates of $\beta$ s from equation (3). Year 2020 is a 0 1 indicator for Mar 2020-Dec 2020. Year 2021 is a 0-1 indicator for the entire year of 2021. Year 2022 is a 0-1 indicator for Jan 2022-Oct 2022. The last three rows report the T-test for equality of the estimated coefficients for two years. 


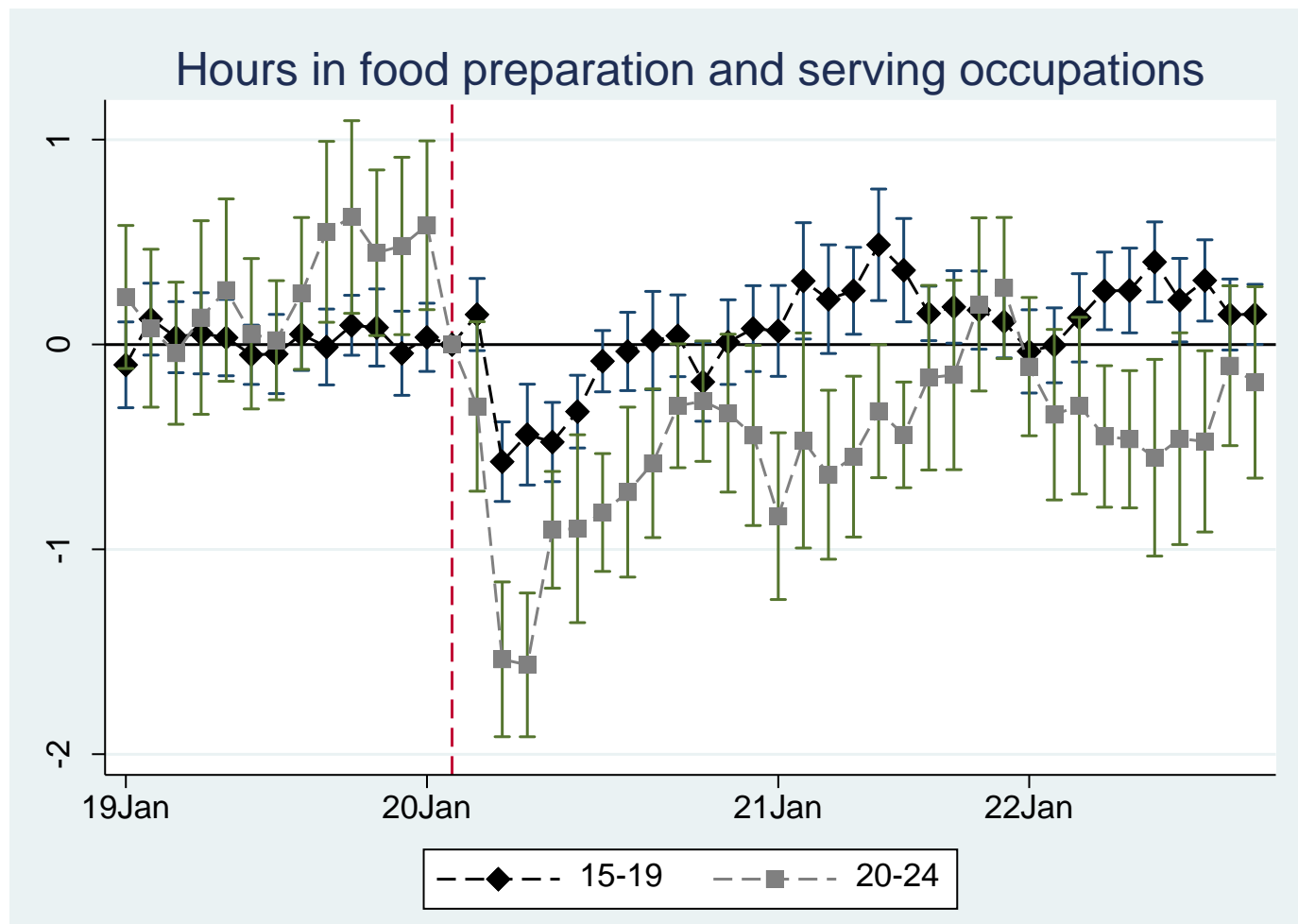

Appendix Figure 1:

Effect of the pandemic on usual work hours in food preparation and serving occupations

Note: Figure shows estimated coefficients and 95\% CIs on month indicators in Eq. 1. 


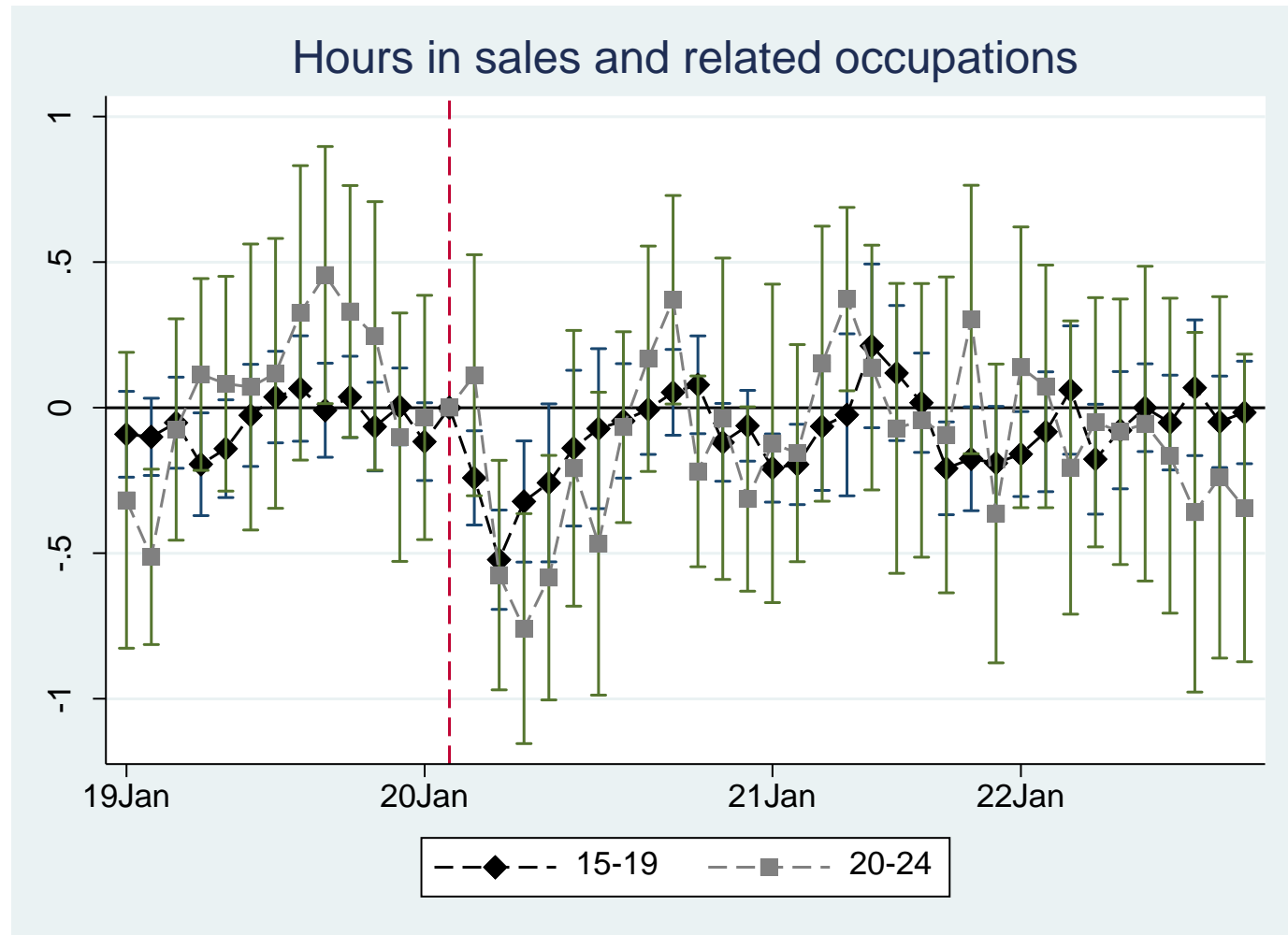

Appendix Figure 2:

Effect of the pandemic on usual work hours in sales and related occupations

Note: Figure shows estimated coefficients and 95\% CIs on month indicators in Eq. 1. 


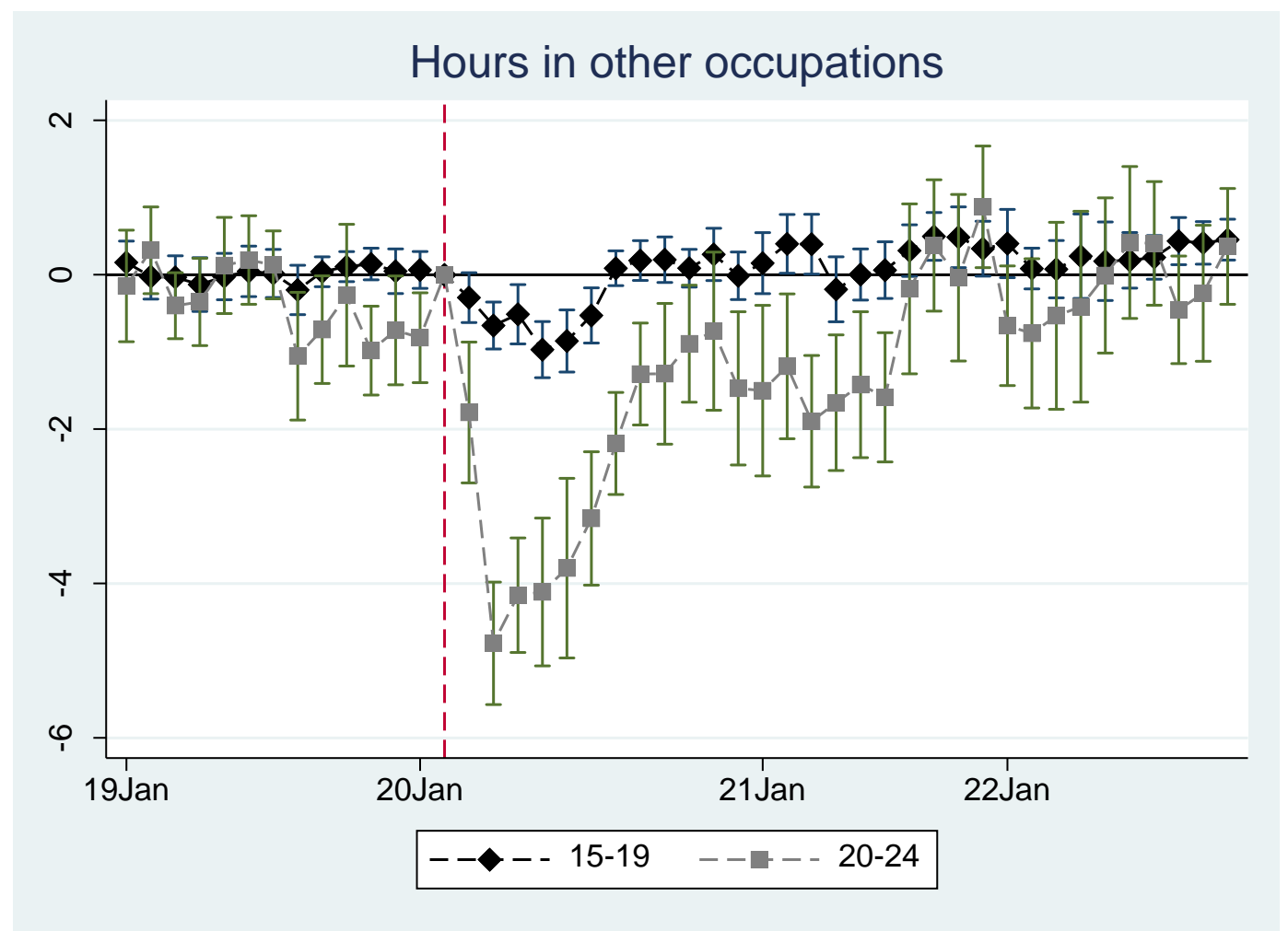

Appendix Figure 3

Effect of the pandemic on usual work hours in other occupations (not food preparation and serving or sales and related)

Note: Figure shows estimated coefficients and 95\% CIs on month indicators in Eq. 1. 


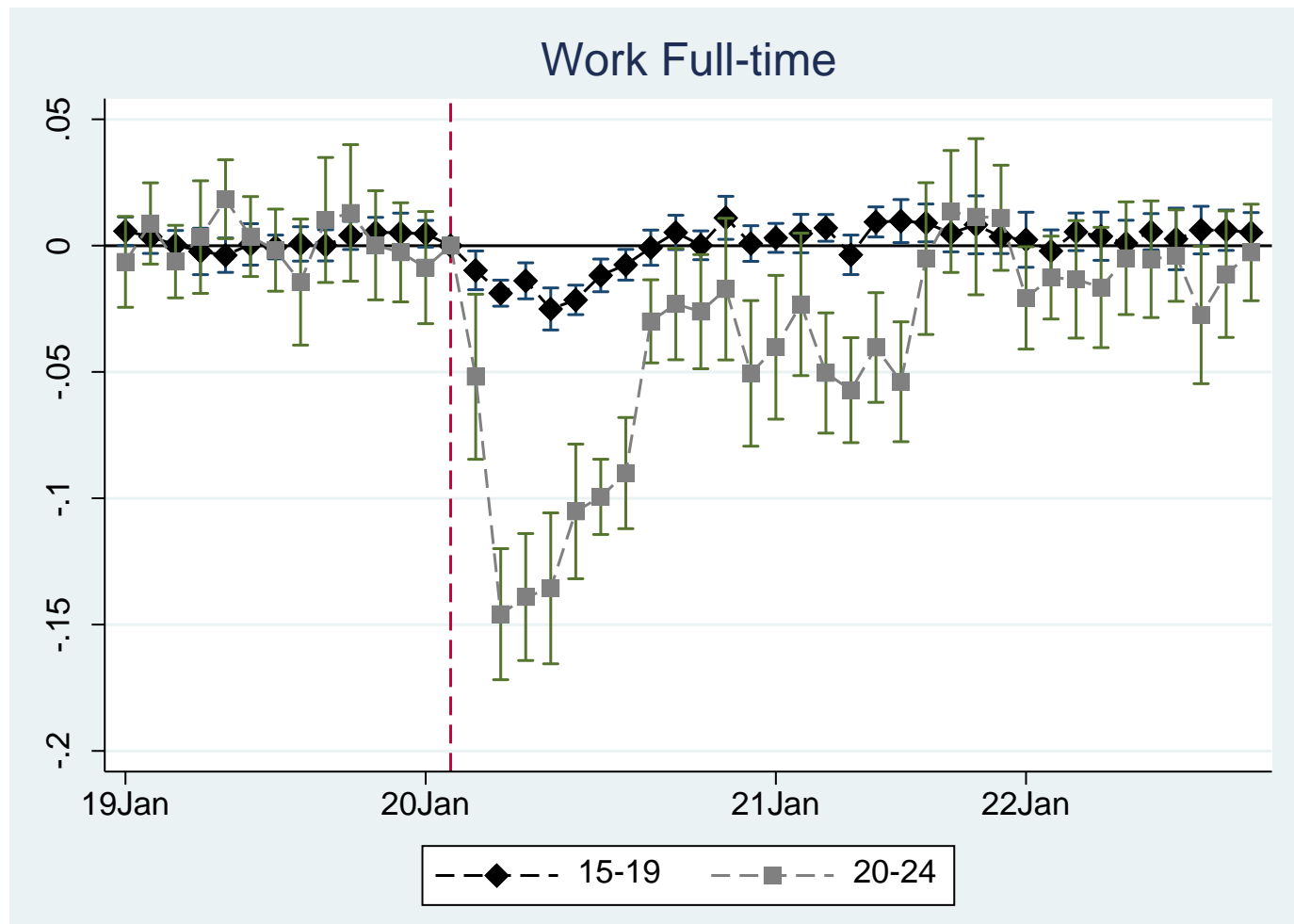

Appendix Figure 4

Effect of the pandemic on full-time employment

Note: Figure shows estimated coefficients and 95\% CIs on month indicators in Eq. 1. 


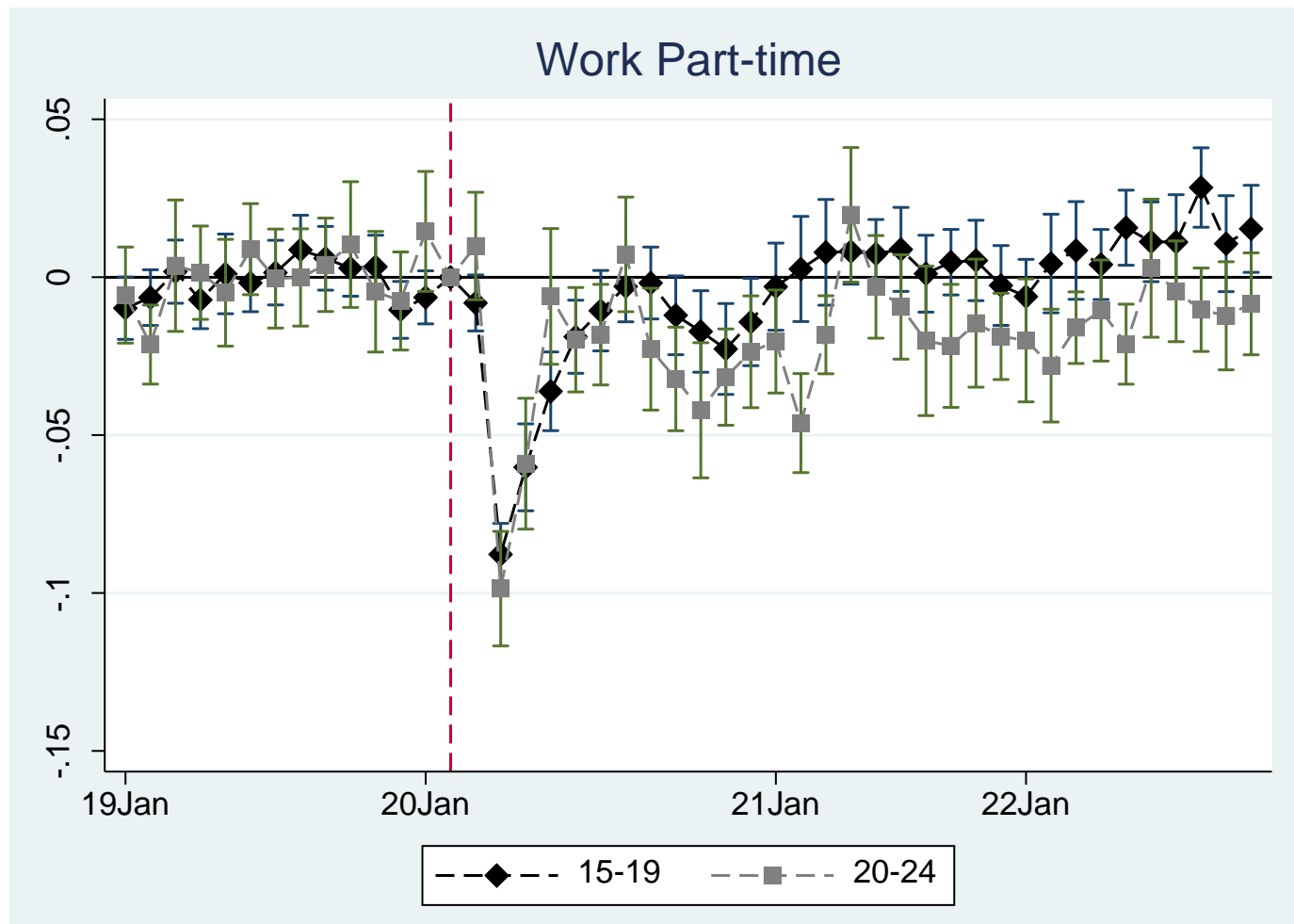

Appendix Figure 5

Effect of the pandemic on part-time employment

Note: Figure shows estimated coefficients and 95\% CIs on month indicators in Eq. 1. 